\title{
Recommendations for investigation and improvement of the effect of solid waste irregular storage area on water sources in Düzce, Turkey
}

\author{
Katı atık düzensiz depolama sahasının su kaynaklarına etkisinin \\ incelenmesi ve iyileştirilmesine yönelik öneriler: Düzce, Türkiye
}

\author{
Hazel ALAN ${ }^{1}$ iD , Remzi KARAGÜZEL2* iD \\ 1,2Engineering Geology, Faculty of Mines, Istanbul Technical University, Istanbul, Turkey. \\ hazel.alan@itu.edu.tr,karaguzel@itu.edu.tr
}

\section{Abstract}

This study has been prepared to clarify the environmental impacts of irregular solid waste disposal sites in Düzce. Solid wastes were found in the Melen dam basin, where the drinking water of the Istanbul metropolitan area was provided and poured on the edge of the Küçük Melen Stream and on alluvium without taking any precautions. Geological and hydrogeological maps of solid waste irregular disposal sites and its surroundings are prepared. In order to determine the groundwater quality in the study area chemical analysis results determined for potability and various usability purposes. The hydraulic connection between the surface and groundwater of irregular solid waste disposal site was evaluated under different environmental conditions and conceptual models were prepared. It has been determined that the solid waste irregular storage site in the study area negatively affects the surface and groundwater quality and the water samples are not suitable for human consumption purposes. As a result, transportation of solid wastes in the drinking water basin from the region to a regular solid waste storage facility or construction of a $45 \mathrm{~m}$ deep all-around impermeability curtain has been seen as secure solution methods. Furthermore, in the condition of the leak water level in the environment which is isolated from the surface water and groundwater is below the natural water level, it will have been prevented the water flow out of the storage facility.

Keywords: Solid waste, Hydrogeology, Field rehabilitation.

\section{Introduction}

In our country, solid wastes are collected under the 'Regulation on Control of Solid Wastes' and the obligations for recycling are fulfilled in a way that will create a negative impact on the environment and human health. In Turkey, the number of solid waste landfill facilities increased to $76 \%$ in respect of 2014 [1] Solid waste collected across the country is disposed of as $\% 6$ by recycling method, as $64 \%$ by regular landfill method and as $30 \%$ by solid waste irregular storage method [2]. Although the legislation related to these issues in Turkey, the negative environmental impacts of irregular solid waste storage sites from past years to the present are continuing.

In order to prevent groundwater contamination, it is essential to determine the distribution of heavy metal concentration in the groundwater system at a solid waste irregular storage area [3],[4]. Various remediation studies are conducted because of
Öz

Bu çalışmada, Düzce Illi'nde yer alan katı atık düzensiz depolama sahasının su kaynaklarına etkisinin belirlenmesi ve iyileştirilmesine yönelik öneriler getirilmesi amaçlanmaktadır. Katı atıklar, İstanbul metropolitanının içme suyunun temin edildiği Melen Barajı havzasında olup, Küçük Melen Cayı kenarında ve alüvyon üzerinde hiçbir önlem alınmaksızın dökülmüstür. Düzensiz depolama alanı ve yakın çevresinin, jeoloji ve hidrojeoloji haritaları hazırlanmıștır. Inceleme alanında düzensiz katı atık sahasının yüzey ve yeraltısuyu kalitesine etkisini belirlemek amaciyla; sahanin menba ve mansap tarafinda temsili noktalardan su örnekleri alınmıstır. Alınan su örneklerinin kimyasal analizleri yapılmış, kirlilik durumları ve çeşitli kullanım alanlarına uygunlukları tartıșlmıștır. Katı atık düzensiz depolama sahasının yüzey ve yeraltısuları ile ilişkisi farklı çevre koşullarında değerlendirilmiș ve kavramsal modeller hazırlanmıștır. Inceleme alanında düzensiz katı atık sahasının yüzey ve yeraltısuyu kalitesini olumsuz etkilediği ve suların insani tüketim amacına uygun olmadıkları tespit edilmistir. Sonuç olarak, içme suyu havzasında bulunan katı atıkların bölgeden düzenli bir depolama tesisine taşınması veya $45 \mathrm{~m}$ derinliğinde çepeçevre bir sızdırmazlık perdesinin inșası güvenli çözüm yöntemleri olarak görülmüş̧ür. Ayrıca, yüzey ve yeraltısularından izole edilecek ortamdaki sızıntı suyu seviyesinin doğal ortam su seviyesinin altında olması depolama tesisinden dışa su akımına engel olacağı tespit edilmiștir.

Anahtar kelimeler: Katı atık, Hidrojeoloji, Islah çalıșmaları.

\footnotetext{
${ }^{*}$ Corresponding author/Yazışılan Yazar
}

environmental problems emerging from solid waste disposal sites [5]. This study aims to propose potential solutions for the determination and improvement of the impact of the solid waste irregular dump site on water sources in the Melen Dam Lake Basin, which is planned to be supplied with drinking water to Istanbul. The solid waste irregular storage site is located on the right bank of the Küçük Melen Stream in the Düzce plain and spreads over an area of approximately $184 \mathrm{~m}^{2}$ (Figure 1).

\section{Methods}

For the purpose of the study, the geological, hydrological and hydrogeological properties of the solid waste irregular storage area and its surroundings have been determined. The hydrological properties of the study area have been calculated to determine the water potential. The temperature, evaporation and precipitation data of the last ten years from the Meteorology Station are taken from Düzce Meteorological 
Station; the amount of rainfall in the basin, the amount of evaporation and the amount of water leaking into the ground were calculated using the Penman method.

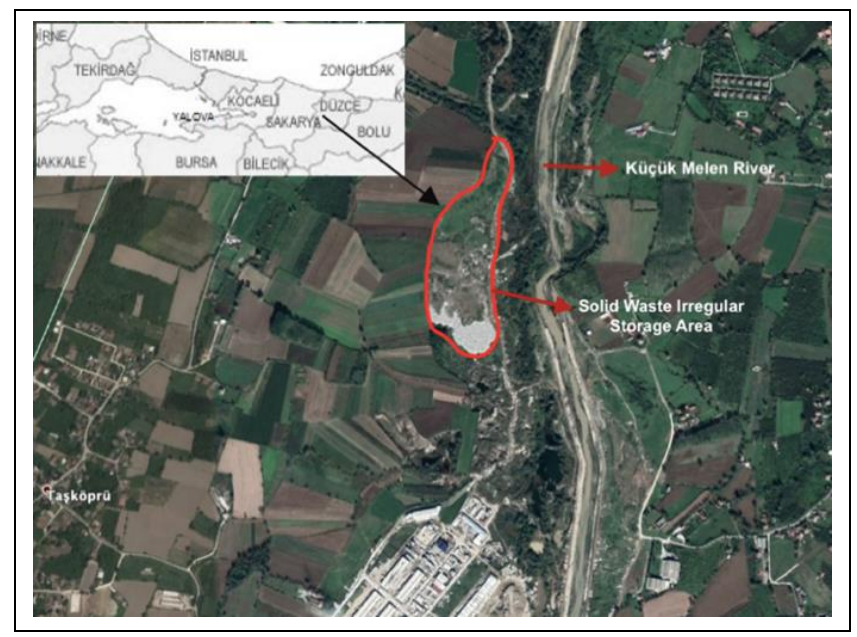

Figure 1. Location map of study area.

In order to determine the hydrochemical properties of the study area, surface and groundwater samples were taken from representative points, and chemical analyzes were performed. One liter of water samples into bottles taken from the study area was kept at $+4{ }^{\circ} \mathrm{C}$ in accordance with the standards and prepared in the laboratory for analysis. The water samples were delivered to the laboratory in 24 hours, and the $\mathrm{pH}$ reduction process was performed in the TÜBITAK MAM Laboratory. Anion-cation and heavy metal analysis of water samples were carried out by the TÜBITAK MAM Laboratory using IC and ICP-MS method. Using the results of the analysis, the contamination conditions of the groundwater were discussed.

Within the scope of engineering geology studies, research pits were opened in order to determine the ground parameters and the ground class of the solid waste storage area. Sieve analyses were performed on the samples taken from the pits and ground parameters were determined. In the light of log data from various drilling wells, geological sections were drawn in various directions and block diagrams were created in order to be able to see the natural position in the storage area.

\section{General geology}

Yedigöller Formation, a Precambrian aged unit, is observed at the northern border of the study area. Kurtköy Formation (Ok) is a Lower Ordovician aged unit which unconformably overlies the Yedigöller Formation (PEy). The Akveren Formation of Upper Campanian-Lower Eocene age consists of white marl, limestone, carbonated sandstone, carbonated shale and cherty limestones. The Lower-Middle Eocene aged Safranbolu formation, which is overlying Akveren formation, outcrops in a narrow area southeast of the study area. The Caycuma formation (Tes) begins with the conglomerate-sandstone level and transitions to the carbonated sandstone-sandy limestones, which is overlying. Yı ̆glca Formation (Tçy) consists of andesite, basalt, tuff, agglomerate and volcanogenic sandstones. It is observed that all clastic sediments that fill the Düzce basin consist of gravel-sand-silt and clays (Figure 2) [6].

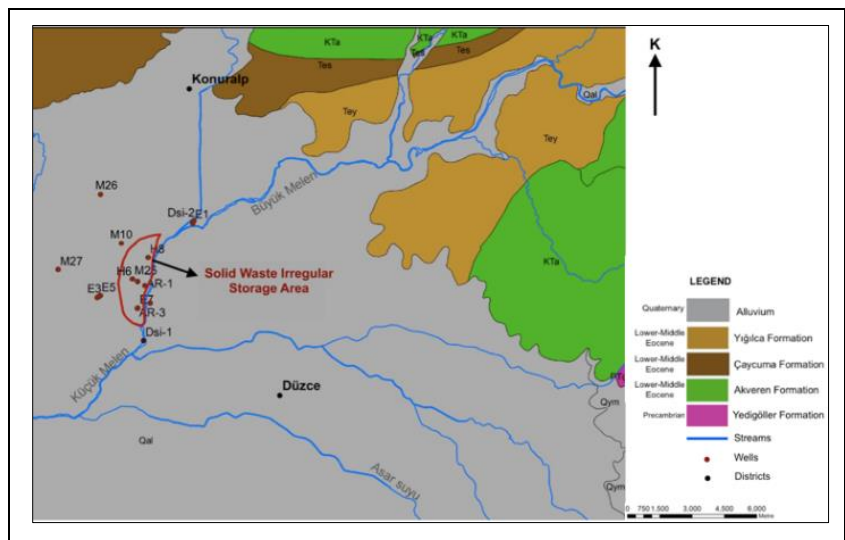

Figure 2. General geology map of Düzce basin and its surroundings [10].

\section{Hydrology}

Hydrological characteristics of the study area are also important in the calculation of the amount of percolating water, both in the rehabilitation of the irregular solid waste storage site and in the discussion of the impact of a new regular solid waste site on water resources. For this purpose, the amount of rainfall, evaporation and flowing water into the basin was calculated by using the data obtained from DüzceMeteorological Station. Calculating the average of 10 -year precipitation data of the study area, the average annual precipitation value was $746.44 \mathrm{~mm}$ and the average temperature value was obtained as $14.22{ }^{\circ} \mathrm{C}$. The actual evaporation value was calculated as $534 \mathrm{~mm}$ by using the Penman method. Accordingly, a flow of $212.42 \mathrm{~mm}$ occurred in the region connected with the precipitation falling into the basin. Precipitation waters are contaminated directly in the groundwater in the solid waste site, which does not have a base impermeability system, especially during rainy periods. In the overflow of the Küçük Melen Stream during the flood to the landfill and feeding the groundwater, both groundwater and surface water are polluted. In cases where there is not adequate measurement data in the water balance calculations, the amount of water percolating to the underground theoretically can be taken as $1 / 3$ of the flow [7]. For the purpose of the study, according to the amount of flow calculated in the region, $70.6 \mathrm{~mm}$ of this flow is percolated to the underground. In addition, it is inevitable that solid wastes stored at the edge of Küçük Melen Stream, which has a maximum flood discharge of $1300 \mathrm{~m}^{3} / \mathrm{h}$ will be negatively affected by this flooding water [8]. These findings indicate that measures should be taken to prevent contact of surface waters with solid wastes on the purpose of maintaining water quality in the study area.

\section{Hydrogeology}

The geological units in the study area were classified according to their physical and hydrogeological properties, and a hydrogeology map was prepared. In this map, unconsolidated formations (alluvium) are defined as "Widespread-Rich aquifers" and the unconsolidated formations as "WidespreadRich Aquifers", "Weakened Aquifers" and "Very Weakened Aquifers". Alluviums that spread over large areas in the Düzce basin have been approximately $260 \mathrm{~m}$ thickness and classified as "Widespread-Rich Aquifer" [9]. The irregular solid waste site is located on the alluviums that forming the most important aquifer systems (Unconfined, two confined aquifers) of the 
region. The groundwater level was measured in research pits opened in the study area. Groundwater level measurements were made during the period when the groundwater level was maximum. Groundwater, which has a very shallow depth $(1.5 \mathrm{~m})$ from the surface, is also used for drinking purposes in the plain. In the October- 2017 period, groundwater levels were measured from the boreholes and the groundwater level map was prepared (Figure 3). It has been determined from the groundwater level map that the groundwater flow direction is from the northeast (from the solid waste irregular storage area) to the southwest. As a result, it is understood that the pollutants reaching the groundwater from the solid waste irregular storage site, which is located on the northeast coast of the plain, will spread over large areas in Düzce plain over time.

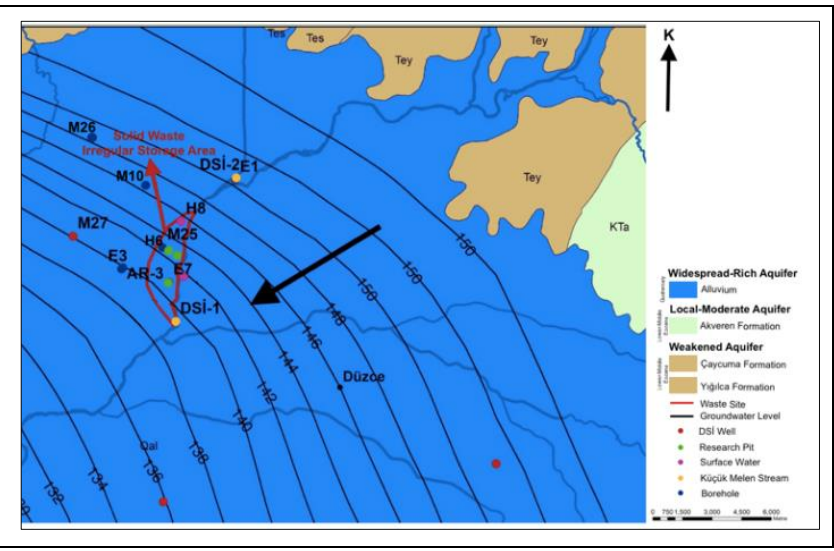

Figure 3. Hydrogeology map of October 2017 period [10].

Engineering geology research was conducted to prevent the impact of the solid waste irregular storage site on water resources. In this scope, the geometric dimensions of the solid waste irregular site $\left(60000 \mathrm{~m}^{2}\right)$ were determined and a threedimensional geological cross-section of the study area was created (Figure 4. Three-dimensional geological cross-section using drilling data in the study area [12].

). In the preparation of this cross-section, water borehole logs opened by DSI were used. In addition, investigations were made in excavations and research pits in the study area. In this scope, three research pits were opened and soil profiles were prepared, disturbed samples were collected and the soils were classified by grain size distribution (sieve) analysis.

It was determined that the soil samples taken from the research pits contain more than $50 \%$ coarse grains and less than $5 \%$ fine grains. As a result, the soil samples with uniformity and curvature coefficients in the range of $\mathrm{Cu}>4$ and $1<\mathrm{Cr}<3$ in the soil classification system made, according to TS 1500 were classified as well-graded (GW) uniformly distributed gravel. The permeability values of lithological units were taken as $10^{-3} \mathrm{~m} / \mathrm{s}$ for gravel, $10^{-5} \mathrm{~m} / \mathrm{s}$ for sand and $10^{-8} \mathrm{~m} / \mathrm{s}$ for clay. Permeability values were determined according to the results of the pumping tests performed in DSI well (4354) and the classification of the soil samples taken from the research pits opened in the study area [10]. The permeability values of the soil samples taken from the research pits are consistent with the permeability values in the literature [11].

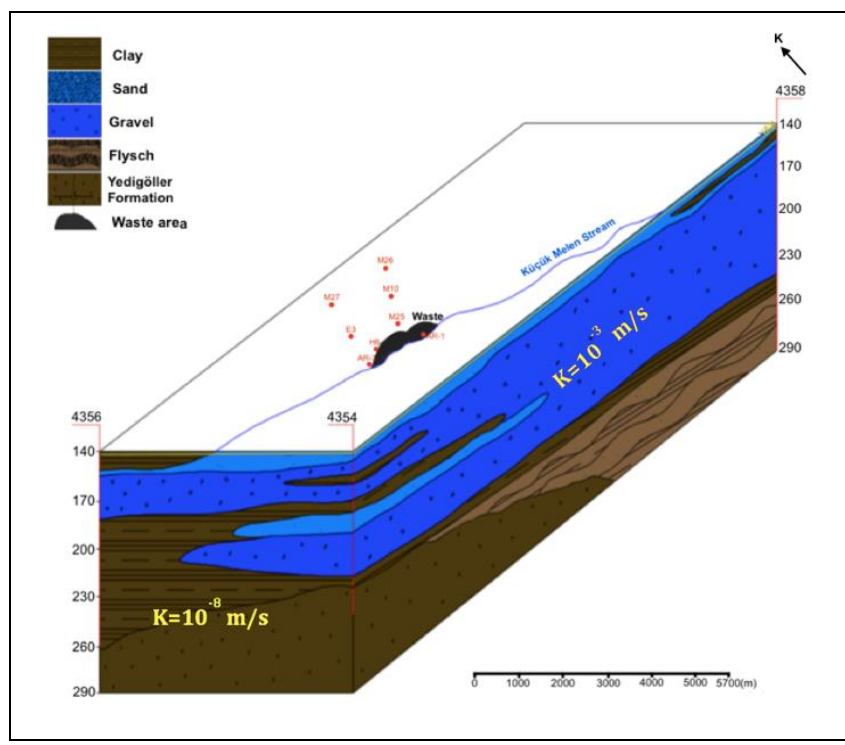

Figure 4. Three-dimensional geological cross-section using drilling data in the study area [12].

\section{Water chemistry and pollution}

In order to determine the quality of surface and groundwater and the degree of being effected from solid waste irregular storage area in the study area, water samples were taken from representative points on the upstream and downstream sides of the site (Figure 5). Hydrogeochemical analysis of the water samples taken from the study area was made, and water classification was made using Schoeller and Piper diagrams (Table 1\&Table 2). In addition, the drinkability and the irrigation suitability of the waters have been determined.

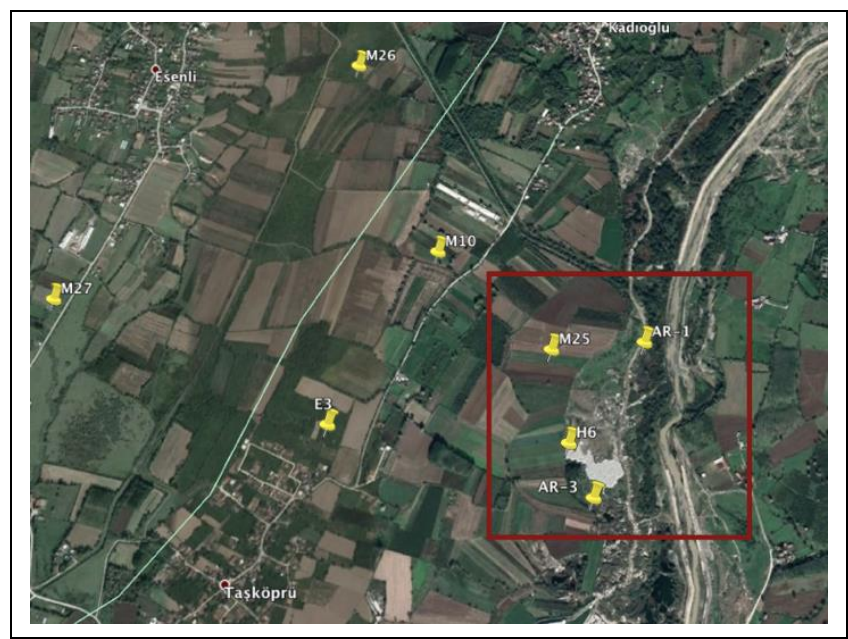

Figure 5. Satellite image of boreholes and research pits in the study area.

In order to determine the facies of the water samples taken from the study area, the \% meq values of the major anions and cations were calculated and shown in the Piper diagram (Figure 6). According to the Piper diagram, the sample $\mathrm{H} 6$ is in the $\mathrm{Na}-\mathrm{HCO}_{3}$ waters class and others are in the with $\mathrm{Ca}-\mathrm{HCO}_{3}$ water class. Sample H6 was taken from the leak-water at the boundary of downstream of the solid waste site. 


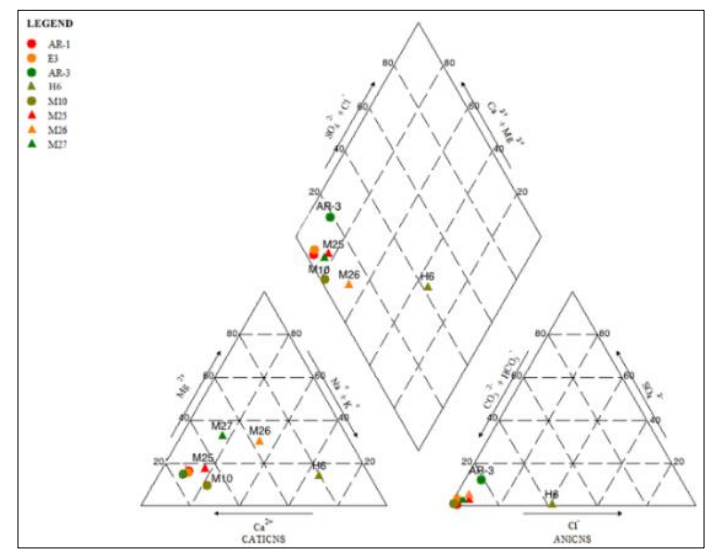

Figure 6. Demonstration of water samples on piper diagram (\%meq).

According to Schoeller water classification, water samples taken from two research pits, five boreholes and one surface leak waters are H6 Medium Chlorinated Water according to the chloride concentration and the others are Normal Chlorinated waters and according to the sulfate concentration all of the water samples are Normal Sulphated [13]. According to the carbonate and bicarbonate concentrations, E3, AR-3, and H6 Hypercarbonated Waters, other water samples were classified as the Normal Carbonated Water (Table 1).

Table 1. Samples not suitable for use according to TSE-266 in terms of major elements and physical properties [14].

\begin{tabular}{|c|c|c|c|c|c|c|c|c|c|c|c|c|}
\hline Parameter & Unit & $\begin{array}{r}\text { TSE-( } \\
\text { Ideal value }\end{array}$ & (266) & шно & AR-1 & AR-3 & E3 & H6 & M10 & M25 & & M27 \\
\hline $\mathrm{pH}$ & & 6.5 & 8.5 & & 8 & 7.5 & 7.5 & 7.6 & 6.5 & 7.7 & 7 & 6.7 \\
\hline empe & ${ }^{\circ} \mathrm{C}$ & 12 & 25 & - & 14 & 13.5 & 15.8 & 13.9 & 17.4 & 14.2 & & $\begin{array}{l}0.7 \\
13.8\end{array}$ \\
\hline trical conductivity $(\mathrm{EC})$ & $\mu \mathrm{S} / \mathrm{cm}$ & 400 & 2000 & & 780 & 850 & 500 & $>5000$ & 370 & 480 & 660 & $\begin{array}{l}480 \\
480\end{array}$ \\
\hline $\mathrm{Cl}^{\circ}$ & $\mathrm{mg} / \mathrm{l}$ & 25 & 600 & 250 & 7.1 & 19.7 & 3.6 & 3249 & 1.8 & 12.5 & 14.6 & 8.1 \\
\hline $\mathrm{SO}_{4}^{-2}$ & $\mathrm{mg} / \mathrm{l}$ & 25 & 250 & 250 & 1.2 & 46.8 & 8.3 & 26.4 & 1.8 & 7.4 & 1.5 & 7.7 \\
\hline $\mathrm{Ca}^{+2}$ & $\mathrm{mg} / \mathrm{l}$ & 100 & 200 & . & 109.8 & 123.3 & 84.9 & 914.6 & 58.2 & 71.1 & 55.6 & 58.7 \\
\hline $\mathrm{Mg}^{+2}$ & $\mathrm{mg} / \mathrm{l}$ & 30 & 50 & - & 14.4 & 14.1 & 10.7 & 366 & 4.6 & 11.1 & 27.1 & 22.5 \\
\hline $\mathrm{Na}^{+}$ & $\mathrm{mg} / \mathrm{l}$ & 20 & 175 & 200 & 14.1 & 15.2 & 14.5 & 2152 & 21.1 & 21.3 & 57.4 & 22.5 \\
\hline $\mathrm{K}^{+}$ & $\mathrm{mg} / \mathrm{l}$ & 10 & 12 & -1 & 10.57 & 4.94 & 1.10 & 2027 & 1.13 & 1.02 & 0.77 & 0.28 \\
\hline $\mathrm{HCO}_{3}$ & $\mathrm{mg} / \mathrm{l}$ & & &. & 448.3 & 403.8 & 336.7 & 7910.5 & 253.2 & 300.7 & 413 & 330 \\
\hline
\end{tabular}
Values that exceed limit values are written in red.

Groundwater in the study area generally shows similar characteristics ( $\mathrm{Ca} 2++\mathrm{Mg} 2+>\mathrm{Na}++\mathrm{K}+$ ) and $\mathrm{HCO} 3->\mathrm{SO} 42->$ $\mathrm{Cl}-)$ in terms of major elements. $\mathrm{H} 6$ has shown different properties ( $\mathrm{Na}+>\mathrm{K}+>\mathrm{Ca} 2+>\mathrm{Mg} 2+$ and $\mathrm{HCO}->\mathrm{Cl}->\mathrm{SO} 42-)$, and the being has different facies was associated with solid wastes (Figure 7).

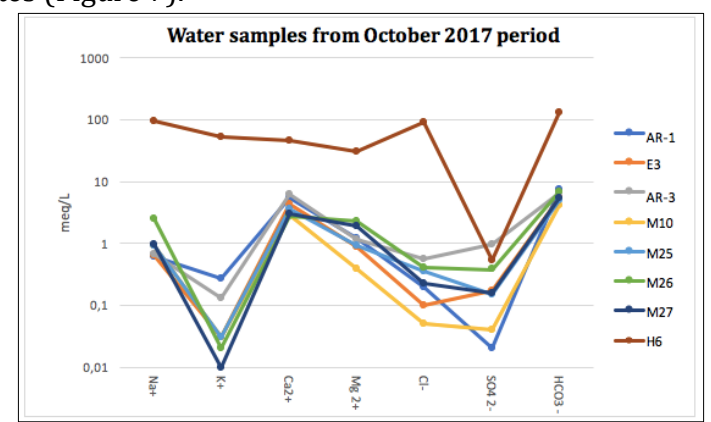

Figure 7. Demonstration of water samples on schoeller diagram.

The heavy metal concentration of the water samples confirmed the degree of contamination of the waters by solid wastes. Heavy metal and nitrous (nitrite, nitrate) concentrations, AR-1, E3, AR-3, M27 water samples were determined as contaminated and being non-potable according to the Human
Consumption Purpose Regulation (Table 2) [14]. Considering the groundwater flow direction, it was determined according to the nitrate concentration that the E3 sample located in the flow direction was affected by the solid waste leachate (Figure 3). In addition, nitrate concentrations of AR-1, AR-3 and E3 were determined to exceed the limit value due to the mixing of solid waste leachate with groundwater. According to nitrite concentration of water samples, M10, M25, M26 and M27 were determined as uncontaminated waters (Table 2). The solid waste surface leak water $\mathrm{H} 6$ that is interacting with the living species in the region, should be rehabilitated as it creates an environmental problem.

Table 2. Drinking properties of water according to the Regulation on Water for Human Consumption [14].

\begin{tabular}{ccccccccccccc}
\hline Parameter Unit & Ideal Value & Max Value & AR-1 & AR-3 & E3 & H6 & M10 & M25 & M26 & M27 \\
\hline $\mathrm{NO}_{3}{ }^{\circ}$ & $\mathrm{mg} / \mathrm{l}$ & 25 & 50 & 4.1 & 30 & 4.2 & 3 & 0.01 & 0.8 & 0.08 & 0.01 \\
$\mathrm{NO}_{2}^{-}$ & $\mathrm{mg} / \mathrm{l}$ & - & 0.1 & 6 & 0.6 & 5.8 & 11.6 & 0.01 & 0.01 & 0.01 & 0.01 \\
$\mathrm{Al}$ & $\mu \mathrm{L} / \mathrm{L}$ & 50 & 200 & 10.3 & 52.3 & 37.8 & 4100 & 5 & 7.6 & 10 & 374 \\
$\mathrm{~B}$ & $\mu \mathrm{g} / \mathrm{L}$ & 1000 & 2000 & 438 & 198.6 & 61.6 & 10670 & 70 & 53.6 & 58.9 & 29.6 \\
$\mathrm{Mn}$ & $\mu \mathrm{g} / \mathrm{L}$ & 50 & 200 & 7318 & 11.4 & 1.07 & 16752 & 69.9 & 3.9 & 400 & 512 \\
$\mathrm{Cu}$ & $\mu \mathrm{g} / \mathrm{L}$ & 100 & 3000 & 7.9 & 27.6 & 3.6 & 116 & 0.05 & 1.9 & 0.6 & 3.2 \\
$\mathrm{Zn}$ & $\mu \mathrm{g} / \mathrm{L}$ & 100 & 5000 & 10.8 & 55.4 & 49.8 & 378.2 & 5 & 94.4 & 5 & 5 \\
$\mathrm{~F}$ & $\mu \mathrm{g} / \mathrm{L}$ & - & 1500 & 0.12 & 0.12 & 0.12 & 0.24 & 0.02 & 0.02 & 0.17 & 0.08 \\
$\mathrm{Ba}$ & $\mu \mathrm{g} / \mathrm{L}$ & 100 & 300 & 144 & 64.6 & 15.2 & 1493 & 24 & 17 & 21 & 18 \\
$\mathrm{As}$ & $\mu \mathrm{g} / \mathrm{L}$ & - & 10 & 1.84 & 0.65 & 0.5 & 197.4 & 0.5 & 0.5 & 0.5 & 1.3 \\
$\mathrm{Cd}$ & $\mu \mathrm{g} / \mathrm{L}$ & - & 5 & 0.04 & 0.04 & 0.05 & 0.84 & 0.05 & 0.05 & 0.05 & 0.05 \\
$\mathrm{Cr}$ & $\mu \mathrm{g} / \mathrm{L}$ & - & 50 & 0.68 & 1.27 & 0.69 & 483.4 & 0.05 & 0.5 & 0.5 & 0.6 \\
$\mathrm{Se}$ & $\mu \mathrm{g} / \mathrm{L}$ & - & 10 & 3.12 & 3.1 & 3 & 6.43 & 1 & 1 & 1 & 1 \\
$\mathrm{Ni}$ & $\mu \mathrm{g} / \mathrm{L}$ & - & 20 & 5.35 & 2.2 & 1.06 & 258 & 0.5 & 0.6 & 0.6 & 6.2 \\
$\mathrm{~Pb}$ & $\mu \mathrm{g} / \mathrm{L}$ & - & 10 & 0.44 & 3.86 & 0.93 & 24.4 & 0.2 & 0.46 & 0.2 & 0.2 \\
$\mathrm{Fe}$ & $\mu \mathrm{g} / \mathrm{L}$ & - & 200 & 26.6 & 98.2 & 25.7 & 11563 & 0.05 & 18.3 & 358.4 & 401.7 \\
$\mathrm{Sb}$ & $\mu \mathrm{g} / \mathrm{L}$ & - & 5 & 0.9 & 0.8 & 0.7 & 10.8 & 3 & 0.2 & 0.2 & 0.2 \\
\hline
\end{tabular}

Values that exceed limit values are written in red.

According to the US Salinity Diagram, water samples taken from boreholes are in good condition in terms of usability as irrigation water (Figure 8).

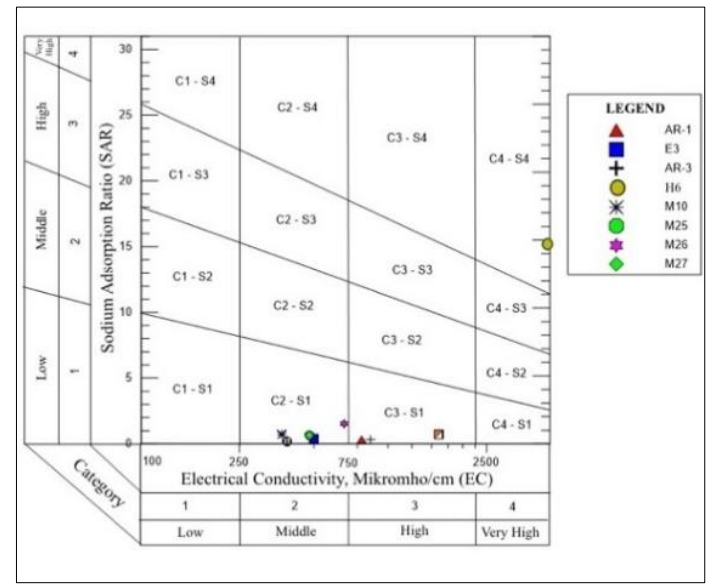

Figure 8. Demonstration of water samples on US salinity diagram.

As a result, according to the evaluation of the chemical analysis of the water samples taken by the downstream of the solid waste irregular storage area, it was determined that the surface and groundwater contaminated in the surrounding of the solid wastes. Furthermore, groundwater contamination is expected to increase due to the presence of solid wastes are located on permeable lithological units, and the groundwater level is deep $1.5 \mathrm{~m}$ from the surface. 


\section{Improvement recommendations}

Within the scope of the rehabilitation practices, first of all, solid wastes in the landfill should be collected in a narrow area as much as possible, and after calculating the number of wastes be conducted. In addition, an impermeable cover system should be planned to inhibit contact of rainwater with solid wastes in order to prevent contamination of groundwater. Thus, the mixing of other contaminants into groundwater, other than the existing leak water in the wastes, will be limited. On the other hand, it is necessary to take precautions against the contamination spreading by raising the groundwater level in the solid waste site, where there is no impermeable base system. The most effective measure against this problem is connecting the vertical impermeability system to a natural impermeable barrier at the base. However, as can be seen from Figure 8, the impermeable layer is $45 \mathrm{~m}$ deep from the waste site. At this depth, the cost of an impermeability barrier was expected to be high. As an alternative to such a high cost solution, numerical analyzes were conducted by using the finite element method in order to determine the effect of impermeability curtain at the shallow depth on the pollution spreading. In this model, the geometric dimensions and boundary conditions of lithological units, wastes, impermeable cover and impermeable curtain were determined. The unit volume weight, permeability and groundwater level parameters were used as boundary conditions (Table 3 ).

Table 3. Boundary conditions of model.

\begin{tabular}{|c|c|c|c|c|c|c|}
\hline \multirow{2}{*}{$\begin{array}{l}\text { Boundry } \\
\text { Condition }\end{array}$} & \multirow{2}{*}{ Waste } & \multicolumn{3}{|c|}{$\begin{array}{c}\text { Lithologic } \\
\text { Unit }\end{array}$} & \multirow{2}{*}{$\begin{array}{c}\text { Impermeabl } \\
\text { Cover }\end{array}$} & \multirow{2}{*}{$\begin{array}{c}\text { Impermeable } \\
\text { Curtain }\end{array}$} \\
\hline & & Gravel & Sand & Clay & & \\
\hline Permeability $(\mathrm{m} / \mathrm{s})$ & $10^{-3}$ & $10^{-3}$ & $10^{-5}$ & $10^{-8}$ & $10^{-12}$ & $10^{-10}$ \\
\hline $\begin{array}{c}\text { Unit Volume } \\
\text { Weight }\left(\mathrm{Mn} / \mathrm{m}^{3}\right)\end{array}$ & 0.0078 & 0.0189 & 0.0149 & 0.0119 & 0.022 & 0.01 \\
\hline $\begin{array}{l}\text { Groundwater } \\
\text { Level }(\mathrm{m})\end{array}$ & 1.5 & 1.5 & 1.5 & 1.5 & 1.5 & 1.5 \\
\hline
\end{tabular}

In order to detect the groundwater contamination in the study area, the hydraulic contact between groundwater and solid waste leachate has been analyzed in three different scenarios. The groundwater level was measured by opening research pits in the study area. Groundwater level measurements were made during the period when the groundwater level was maximum (May 2017). Due to the groundwater is $1.5 \mathrm{~m}$ deep from the surface and solid waste is located on the permeable lithological units, the solid waste leachate and groundwater are in hydraulic contact (Figure 4. Three-dimensional geological cross-section using drilling data in the study area [12].

\section{and Figure 9).}

Scenario-I indicates the groundwater level model findings (horizontal flow velocities and vectors) in the natural condition of the solid waste storage site (Figure 9). It is seen that from this scenario-I model findings there is no horizontal groundwater flow in the solid wastes. In Scenario II, the groundwater flow model of the Küçük Melen Stream in the flooding condition was made. In Scenario III, groundwater flow model analysis was made for different depths of an impermeability curtain that did not reach the impermeable base.

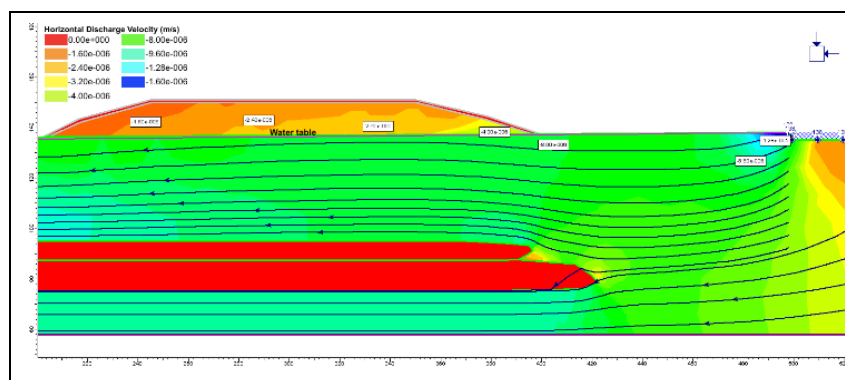

Figure 9. Horizontal flow velocities and vectors of groundwater in natural state in solid waste storage area.

In case of Küçük Melen Stream overflowing 2 m (Scenario II), it has been observed that the water table rises by $2.6 \mathrm{~m}$ in the solid wastes and groundwater flow was occured in the solid wastes (Figure 10).

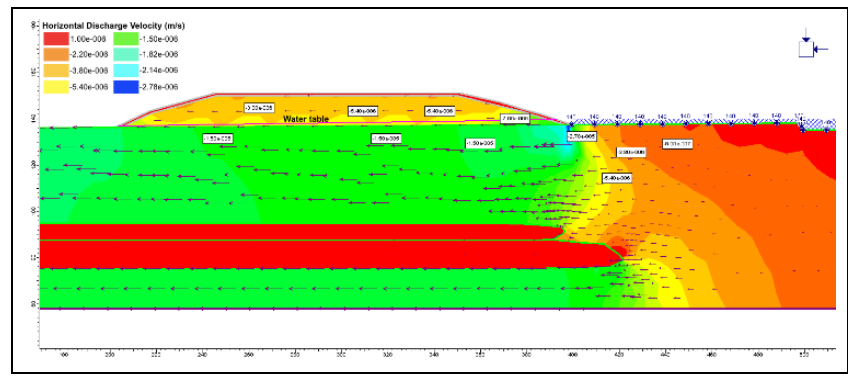

Figure 10. Horizontal flow velocities and vectors of groundwater in case of flooding in the solid waste storage area.

In Scenario-III, analyzes were repeated for impermeable curtain systems at different depths in order to reduce the water table rising in overflowing situation. In a condition of the impermeability curtain depth is $10 \mathrm{~m}, 20 \mathrm{~m}$ and $30 \mathrm{~m}$, decreasing of groundwater level by $35 \mathrm{~cm}, 62 \mathrm{~cm}$ and $88 \mathrm{~cm}$ have been observed in the analysis (Figure 11).

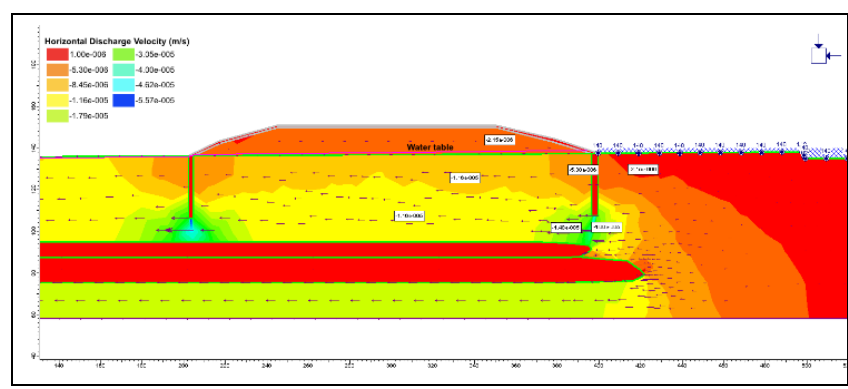

Figure 11. Horizontal flow velocities and vectors of groundwater when a $30 \mathrm{~m}$ impermeable curtain is applied in the flood in the solid waste storage area.

However, these values are lower than the rise at the moment of flood. For all that, it was observed that the horizontal flow decreased significantly at the base of the waste field. In case of the vertical impermeable system is lowered to the natural impermeable clay layer on the base $(45 \mathrm{~m})$, solid wastes covered with impermeable clay were completely isolated from the surface water and groundwater (Figure 12). 


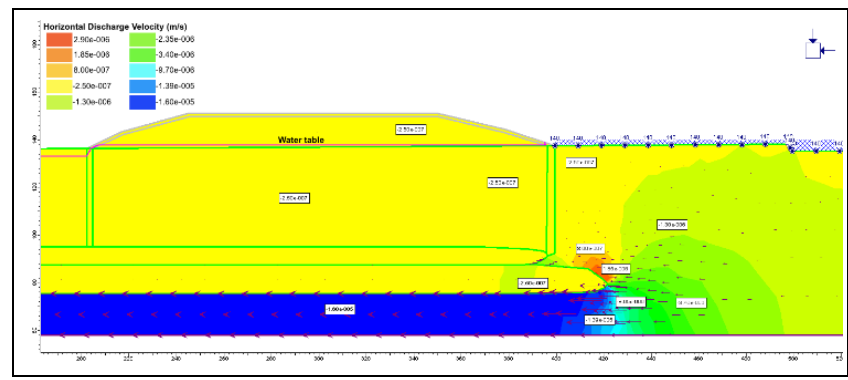

Figure 12. Horizontal flow velocities and vectors of groundwater when $45 \mathrm{~m}$ impermeable curtain is applied in flood in the solid waste storage.

As a result, transportation of these solid wastes in the drinking water basin from the region to a regular solid waste storage facility or construction of a $45 \mathrm{~m}$ deep all-around impermeability curtain has been seen as secure solution methods. Furthermore, in the condition of the leak water level in the environment which is isolated from the surface water and groundwater is below the natural water level, it will have been prevented the water flow out of the storage facility.

\section{Conclusion}

This study conducted to evaluate the environmental impact of the solid waste irregular site; geological, hydrological, and hydrogeological properties of the study area and its surroundings were determined. Geology and hydrogeology maps of the study area were prepared and it was observed that solid wastes were stored in a permeable alluvial environment and the groundwater depth was $2 \mathrm{~m}$ from the surface. It has been determined that the solid waste irregular storage site in the study area negatively affects the surface and groundwater quality. It was determined that the water samples are not suitable for human consumption purposes. Hence, it has been observed that rehabilitation applications are compulsory by evaluation of these results. In the numerical analysis model prepared to minimize the negative impact of solid wastes on the environment, an impermeable curtain system at an economical depth has not been obtained in order to prevent groundwater contamination. However, it has been observed that an impermeable curtain system with a depth of $30 \mathrm{~m}$ could decrease the rise and flow of groundwater level in the wastes to a certain extent. As a result, transportation of these solid wastes in the drinking water basin from the region to a regular solid waste storage facility or construction of a $45 \mathrm{~m}$ deep allaround impermeability curtain has been seen as secure solution methods. Furthermore, in the condition of the leak water level in the environment which is isolated from the surface water and groundwater is below the natural water level, it will have been prevented the water flow out of the storage facility. In addition, gas drainage also should be planned in the rehabilitated storage facility.

\section{References}

[1] T.C. Çevre ve Şehircilik Bakanlığı. "2003 Yılına Kadar 15 Olan Katı Atık Tesisi, 2014 Yılı İtibari İle 76'ya Yükseldi" csb.gov.tr (28.06.2014).

[2] Türk Mühendis ve Mimarlar Odası Birliği-Çevre Mühendisleri Odası. "Dünya Çevre Günü Raporu”. Ankara, Türkiye, 31, 2018.

[3] Beyene H, Banerjee S. "Assessment of the pollution status of the solid waste disposal site of addis ababa city with some selected trace elements". Ethiopia, World Applied Sciences Journal, 14(7), 1048-1057, 2011.

[4] Samuding K, Rahman MTA, Abustan I \& Isa MH. "Heavy metals profiles in a groundwater system at a solid waste disposal site Taiping, Perak". Bulletin of the Geological Society of Malaysia, 58(1), 9-14, 2012.

[5] Hogland W. "Remediation of an old landsfill site soil analysis, leachate quality and gas production". ESPR-Environmental Science \& Pollution Research, Special Issue 1, 49-54, 2002.

[6] Özmen B. “Düzce-Bolu Bölgesi'nin Jeolojisi, Diri Fayları ve Hasar Yapan Depremleri, 12 Kasım 1999 Düzce Depremi Raporu". Deprem Araştırma Dairesi, Ankara, Türkiye, 1$14,2000$.

[7] Hölting B. Hydrologie Einführung in die Allgemeine und Angewandte Hydrologie 2. 36-40, Auflage, Enke Verlag, Stuttgard, 1984.

[8] Devlet Su İșleri. “Türkiye'deki Barajlar”. Ankara, Türkiye, 306, 1991.

[9] Ünsal N, Çelik M. "Hydrogeochemistry and Water Quality Evaluation along the Flow Path in the Unconfined Aquifer of the Düzce Plain, North-western Turkey". Acta Geologica Sinica-English Edition, 84(1), 213-222, 2010.

[10] TÜBITAK Marmara Araştırma Merkezi. "Melen Barajı Havzası Özel Hüküm Belirleme Projesi”. Gebze-Kocaeli, Türkiye, 2017. (Yayımlanmamış Rapor).

[11] ASTM D2434-19. "Standard Test Method for Permeability of Granular Soils (Constant Head)". ASTM International, West Conshohocken, PA, 2019.

[12] Alan H, Onaral N, İzmirli E. Düzce Belediyesi Katı Atık Düzensiz Depolama Sahasının Su Kaynaklarına Etkisinin İncelenmesi ve İyileștirilmesine Yönelik Öneriler. Lisans Tezi, İstanbul, Türkiye, 2018.

[13] Schoeller H. Les Eauv Souterrailnes. $1^{\text {st }}$ ed. Paris, France, Masson, 1962.

[14] Türk Standartları Enstitüsü. "İnsani Tüketim Amaçlı Sular Hakkında Yönetmelik”. Resmi Gazete, Ankara, Türkiye, 266, 2005. 